\title{
SEASONAL WORKER SCHEMES: CAN THEY ACHIEVE SOCIAL JUSTICE?
}

\author{
Ruth McAreavey \\ School of Geography, Politics and Sociology, Newcastle University \\ Newcastle upon Tyne, NE1 7RU: United Kingdom \\ ruth.mcareavey@ncl.ac.uk
}

\begin{abstract}
Seasonal workers are increasingly being used globally to provide a short-term workforce, filling positions in the labour market that are often difficult, dirty and shunned by native born workers. Seasonal schemes are promoted in typically economic terms, offering a triple win where the host society gains from flexible labour; the sending country benefits from remittances and skill transfers; and migrants themselves gain from access to the labour market. However, they have been found to support the uneven economic participation of workers in global production processes and they typically marginalise workers socially. Drawing from examples elsewhere and using Nancy Fraser's three-dimensional perspective of social justice (2005), this article examines the prospect for developing socially just seasonal work programmes. It is logical that most societies seek to promote seasonal worker schemes that allow workers to be treated according to the rules of justice. And yet, research has shown the exploitation of many different types of migrant workers. Following Fraser, the article asks to what extent recognition, redistribution and representation can be achieved through seasonal worker schemes? It identifies key issues for consideration if social justice is to be upheld.
\end{abstract}

Keywords: agri-food, migration, seasonal worker schemes, social justice.

\section{Introduction}

Globally migration today remains at a rate of about 3\% of the total world population, a figure that has been steady for a very long time (de Haas, Castles \& Miller, 2019). Not all migrants are captured by statistics, not all move in a linear fashion nor do they fit neatly into preconceived categories (Crawley \& Skleparis, 2017). Despite this, many different types of individuals are recognised in the 21st century under the catch-all label of migrant. These labels emerge from popular discourse in society and result in the use of terms including economic migrants, refugees and asylum seekers all of which infer particular meaning in that society. For instance, the concept of the 'bogus asylum seeker' was used widely by UK media and politicians in the 1990s referring to perceived problems caused by people at the border (Goodfellow, 2019). Labels are important as they contribute to meaning, behaviour and ultimately, effect access to resources.

State level laws influence the ability of individuals to live and work in a country. Preibisch (2011) argues that immigration restrictions include people differentially, according to their skills and qualifications, and results in different opportunities and privileges. Entry for lower skilled workers provides little in the way of rights and tends to be channelled through temporary and 
seasonal programmes (OECD, 2014). It is of little surprise to discover the institutionalization of exclusion through the creation of quota systems for immigrant workers for sectors that are shunned by the native-born population (Kritzinger, Barrientos \& Rossouw, 2004; Calavita, 2005).

The paradox of migration policy has been wryly observed by many researchers (see for instance Joppke, 1998; Castles, 2006b; Scott, 2017) where nation states operate a policy of economic openness alongside, often vicious, rhetoric that seeks to control migration. This generally results in freedom of movement for goods but not for humans who are controlled by migration policies. Geiger and Pécoud (2014) argue that only relatively recently has migration become 'recognised by states as a topic worthy of attention at the international level' (p.869). This has been evident by the sharp rise in international organisations around the turn of the last century with a remit to encourage co-operation on migration (Newland, 2010). One of the outcomes from this expansion of migration bureaucracies has been the apparent depoliticization of migration with emphasis on neoliberal representation of migrants as entrepreneurial agents and a false projection of openness, even though the reality is of control and restriction (Geiger \& Pécoud, 2014).

Economic restructuring within post-industrial societies has created demand for a low cost and pliable workforce on the one hand (Standing, 2008) and yet nation states simultaneously face political pressure to curtail free movement and immigration (Koehler, Laczko, Aghazarm \& Schad, 2010). Nowhere is this more starkly observed than in Trump's America where pledges to build a wall to exclude Mexicans from entry to the USA are juxtaposed with evidence showing how the economy will need all types of migrants, including those working in low wage jobs (Cassidy, 2018, June 28; Kosten, 2018, June 5; Porter \& Russell, 2018, June 20). Of course, migrants have for a long ime been important in food systems in the USA and in Canada. For example, Preibisch (2011) explains how Chinese immigrants were limited to working in low wage jobs on Canadian farms in the late 19th and early 20th centuries. The use of immigrants in agri-food across Europe has also become the norm, creating pathways for migrants to new destinations in places with little history of rural migrant labour, including Greece, Ireland, Norway and Sweden (Jentsch \& Simard, 2009; Kasimis, Papadopoulos \& Pappas, 2010; McAreavey 2017b).

The pathways for migrants working in agri-food systems have evolved over time. The emergence of bilateral agreements in Canada in the 1960s, institutionalised the employment of international migrants and created a benchmark in seasonal worker programmes (Preibisch, 2011). They are characterised by circularity in that labour migrants work in a country for a number of months, before returning home for the rest of the year. They will continue with this pattern for a period of years, circling between the two countries but never settling permanently in the country of work. This circularity is a benchmark for the success of guest-worker programmes (Hennebry \& Preibisch, 2012). More generic temporary migration programmes (TMP) are on the increase due to evolving labour market demands and restrictions on citizenship (Gilbert, 2014; Strauss \& McGrath, 2019). In Canada, Strauss and McGrath (2019) report how in 2008, for the first time, the number of non-permanent residents entering the country $(399,523)$ exceeded the number of permanent immigrants $(247,243)$. Migration is thus managed by modern economies in such a way that unskilled workers are generally employed on temporary contracts and are denied a route to citizenship as they might have been in the past (Breen, 2016; Strauss \& McGrath, 2019). This contrasts with professional migrants in permanent work who have a clear pathway to citizenship. TMPs afford migrants limited access to public goods in the form of welfare, housing and education giving them little agency to negotiate (Prebisch, 2010). TMPs, particularly agricultural programmes, are recognized as being exploitative due to a range of issues including long working days without overtime; labour market segmentation; use of dangerous chemicals with no safety equipment or training; pay discrimina 
tion between migrant and non-migrant workforce; being prohibited from collective bargaining; downward pressure on workers' wages; and debt bondage (Preibisch, 2010; Hennebry, 2012; Hennebry \& Preibisch, 2012; Lenard \& Straehle, 2012; LeBaron, 2014; Strauss \& McGrath, 2019).

This article contributes to the body of literature that considers the role of migrants in the agri-food sector and the agency of migrants within TMPs. It is timely given the UK's exit from the European Union resulting in a gap in seasonal labour (DEFRA, 2019), the creation of a pilot seasonal worker scheme in the UK and a more general increasing tendency for western economies to use migrants to fill precarious positions in the labour market. It focuses particularly on seasonal agricultural schemes as a means of exploring the extent to which they can ever be socially just and uphold the human rights of individuals. The article begins by setting out what is meant by social justice before going on to consider migrants in the agri-food sector. Following that, seasonal worker schemes are scrutinised. The article concludes with suggestions on what a socially just seasonal worker scheme might look like.

\section{Understanding Social Justice}

Addressing critiques targeted at her two-dimensional model of social justice encompassing recognition and redistribution (Fraser, 1996), Nancy Fraser subsequently added representation to the mix, creating what three constituents of social justice - representation, recognition and redistribution. She showed how these processes occur across economic, cultural and political spheres (Fraser, 2005; Hölscher, 2014). Achieving social justice relies on mutual reinforcement of all dimensions and is fundamentally about participatory parity: what does it take for all to participate on an equal footing in social life? This implies the institutionalisation of fair and just relations between individuals in a society where they can expect to be treated with respect and be afforded full opportunity to advance their position, if they desire. A socially just approach seeks to impede institutional norms that belittle some categories of people or destructive behaviours, attitudes and claims (Fraser, 2005). Many obstacles exist to achieving social justice, including economic inequities; unequal treatment of different ethnic groups; and asymmetric power relations that privilege certain groups while disadvantaging others (Hölscher, 2014). Importantly all elements are critical and are intertwined and are fundamental within a wider social justice framework (Fraser, 2005). Thus, it is not about a question of more emphasis on one pillar over another such as redistribution at the expense of recognition, i.e. class politics over identity politics. This contrasts with Honneth's $(2003,2005)$ alternative theory of recognition where recognition underpins justice and redistribution merely fulfils a sub-category (Garrett, 2010).

Social justice has been criticised on many fronts including that it lacks conceptual clarity and that it does not recognise the pivotal role of the state (Mullaly, 2002). Space does not afford the luxury of full analysis of those critiques in this article. Suffice it to say that Fraser has since provided robust elaboration of her original concept where the state is especially explicit (Fraser, 2005). Here, and in distinction to Honneth's approach, she makes it clear that the issues underpinning social justice transcend individual failings, they are not about psychological shortcomings (Hölscher, 2014). This follows the belief that misrecognition by others does not automatically result in a permanently damaged life (Garrett, 2010). It is not to deny that individuals want to be recognised and that it is without consequence. Recognition is a fundamental human trait and it is relational, achieved through negotiation with others (Taylor, 1992). Indeed, in the context of migration, misrecognition has been shown to be harmful for migrants working in the agri-food sector, causing identity 
disruption and preventing upward mobility (McAreavey, 2017a). However, wider structures frame individual interactions and so greatly influence the degree to which social justice is achieved.

Accordingly, and moving our gaze away from the individual alone, Fraser (2005) introduces the notion of (mis)framing. Frame setting is about creating boundaries which by its very delineation excludes certain groups and in so doing has the capacity to determine social justice. Misframing is a defining form of injustice in the global age (Fraser, 2005) and it can be understood through scrutiny of the processes of how boundaries are drawn as well as understanding the question of 'who' is included (Fraser, 2005). These matters are particularly salient in a globalised world where territorial states can take decisions that have an impact on other states leading some to observe that the 'social processes shaping their lives routinely overflow territorial borders' (Fraser, 2005). Inevitably it leads to decisions about who is included and who is excluded and the resources to which they have access. Fraser's framework has been effectively used to understand migration and individuals' interactions with social structures (Hölscher, 2014). In the remainder of this article, I deploy Fraser's concept of social justice as a means of understanding seasonal worker schemes.

\section{Injustices in agri-food systems}

Power imbalances characterize modern food systems and the food system provides an excellent example of multiple injustices. Perhaps most pertinent is that of the 'stuffed and starved' where obesity exists alongside food poverty (Patel, 2007): about two billion adults are now overweight or obese while an estimated 821 million people remain undernourished (FAO, 2018). Just as there are people who cannot afford to eat, others have been encouraged to eat nutrient empty foods that are highly calorific, leading to a large increase in health problems, something that has been referred to as an 'epidemiological transition' in developing countries (Karar, Alam \& Streatfield, 2009).

The way that food is produced and consumed has been transformed with more concentrated supply chains and power among a few key players (Lang, Barling \& Caraher, 2001; Clapp \& Fuchs, 2009; Hinrichs, 2014). For example, the Big Three - Bayer-Monsanto, Corteva, and Syngenta-ChemChina capture $75 \%$ of the global agricultural input market. Technology has changed food production too, including extending growing and harvest periods. Lawrence, Sippel and Burch (2015) argue that increased financialization and corporatization of the agriculture industry have brought various upstream (e.g. financial institutions, input producers) and downstream interests and agencies (e.g. processors, distributors, retailers) into the food value chain. These changes have squeezed producers' profit margins and have placed more and more pressure on reducing costs and offering cheap food (Clapp, 2016). Despite the prevalence of cheap food, Carolan (2011) shows how actual costs are not reflected in the monetary value of food. On the contrary, he argues that food produced in modern food systems is very expensive and many social justices abound including that future generations will be picking up the high costs of 'cheap' food today (Carolan, 2011). These concerns are reflected more widely in the literature, raising questions about the relationships between industry and the state; environmental degradation; climate change; the position of more vulnerable groups; wider systemic inequalities; and the capacity and sustainability of the system overall (Barling, Lang \& Caraher, 2002; Angus, Burgess, Morris \& Lingard, 2009; Clapp \& Fuchs, 2009; Hinrichs, 2014; Irwin, McAreavey \& Murphy, 2014; Kirwan, Maye \& Brunori, 2017). With squeezed profit margins in agri-food, producers are under constant pressure to decrease costs and so wages are also limited and conditions characterized by uncertainty, risk and insecurity; this contributes to a high concentration of migrant labour (Anderson \& Ruhs, 2010; Gertel \& Sippel, 2014). 
Not surprisingly, there is wide recognition that prevailing food governance systems are no longer fit for purpose due to this concentration of control and subsequent questions of legitimacy, power, resources and interactions of relevant actors within agri-food governance (Hinrichs, 2014). Accordingly, contemporary research on food systems is concerned with different forms of change (see Hinrichs, 2014 for an overview), specifically transition, which 'implies a gradual, pervasive shift from one state or condition to something different' (Hinrichs, 2014, p.144) and which involves adjusting imbalances and addressing 'design faults' (Richardson, 2018, p.218). This aligns with Fraser's (2005) approach to social justice which calls for critical reflexivity among those with a voice to bring about change so that more vulnerable groups are properly represented, and ultimately appropriate distribution and recognition ensues.

\section{Migrants working in the agri-food sector}

A common claim is made that locals reject the roles that migrants are willing to do. In many places, including the USA, Canada, Australia and many parts of Europe, migrants have embodied what it is to be 'good' workers in contrast to local people who reject the dangerous, dirty and demeaning work across the agri-food sector (Rogaly, 2008; Anderson, 2010;, McAreavey, 2017a). However, the alleged workforce shortage is political and Sharma (2001) describes a shortage of 'a particular kind of work force that is cheap, politically repressed and so on' (p.67), while Geddes and Scott (2010) argue that reliance on migrant workers in low skilled jobs is constructed. In other words, employers have contributed to a process where low-skilled and casual workers are embedded and this has allowed them to extend harvests, intensify production and generally respond to the structural transformation of food systems. In this way migration regimes become a tool for employers to undermine wages and working conditions (Strauss \& McGrath, 2017) and to pass uncertainty that is inherent in the sector on to migrant workers (Geddes \& Scott, 2010). Producers can respond in a very flexible way to short term spikes in demand for labour, avoiding the need to invest in expensive capital equipment by employing low wage and casual workers - migration regimes support this process.

Not all seasonal workers travel under recognised seasonal worker schemes nor are they employed through legitimate means. Hoggart and Mendoza's (2002) seminal study of African workers in Spain in the 1990s illustrates this very plainly. Although several decades old, the study persuasively illustrates the messiness around seasonal and temporary work and the precarity faced by short term workers in a labour market without appropriate protection structures. They show how easy it is for workers to 'slip' into illegality where processes of obtaining correct legal documents are overly complex. Many of the workers in their study were employed in seasonal activities and yet many of them identified as wishing to remain permanently in Spain. A series of different (short term) contracts issued by employers meant that they avoided providing workers with continuous employment for over three years. Consequently, those workers were effectively permanently temporary, with dubious accompanying rights and they lacked political voice to defend their interests and to challenge their mis-framing as temporary workers. The agricultural workers were also mis-recognised, due to their ethnic status, as being suitable for difficult work; they had low social status, enjoyed little economic mobility and received low wages. Their inability to articulate their rights exacerbated their misrepresentation (Fraser, 2005). This has been evidenced more widely in rural society and is characteristic of certain streams of migration to European peripheries (Rye \& Andrzejewska, 2010; McAreavey \& Argent, 2018; Papadopoulos, Fratsea \& Mavrommatis, 2018.

There is a general trend of an increased secondary 'precarious' labour market in agriculture (and indeed elsewhere) and a declining primary labour market characterised by high capital investment, good working conditions and prospects of upward mobility (Piore, 1979). In short, work 
in the secondary labour market is a means to an end and does not build status (Piore, 1979). For instance, migrants become wage earners, working in one country to achieve ambitions elsewhere, such as building a house in their home country. This also affords them status and recognition, something that they may struggle to achieve while working in the secondary labour market. Such concerns relating to economy, culture and politics relate directly to the fundamentals of Fraser's model of social justice, how key actors are framed and recognized; wealth distribution; and how diverse interests are represented.

\section{Seasonal Work Schemes}

Seasonal work is related to temporary employment linked to specific times of the year such as the harvest season or the skiing season; employment therefore fluctuates or is restricted according to the season or time of the year. The European Commission understands seasonal work as activity that is tied to a certain time of the year by a recurring event or pattern of events linked to seasonal conditions and is governed by Article 3(b) of Directive 2014/36/EU2 ${ }^{2}$. Workers are afforded restricted rights to enter and work; activities are often low skilled; and, in general, the workplace is precarious and poorly paid (Ruhs, 2013). These 'conditions' are accepted by workers as they pursue wider goals of remitting and more generally of improving their life back home (and that of their family). There is an implicit assumption that migration is a 'good thing'. For instance, the International Organisation for Migration (IOM) argues that circular and seasonal migration is a recognised strategy for certain groups such as communities in the Naryn River Basin in Kyrgyzstan to manage risks arising from environmental hazards (IOM, 2019). And so the argument goes that migrating for work can facilitate transitioning economies to move from subsistence farming to more commercially oriented activities, with the inherent assumption that this is a positive thing. However, questions have been raised about the lack of appropriate data on the relationship between development and migration (Apthorpe, 1997).

Nonetheless, the importance of the development-migration nexus is visible in New Zealand's Recognised Seasonal Employer Scheme (RSE) where just under 10,000 Pacific Islanders were granted visas under RSE in 2017-2018. IOM maintains that such is the impact of seasonal work for Pacific Islander communities that they are diversifying their emigration routes into Japan in addition to the established Australian and New Zealand routes (IOM, 2019). There is evidently a strong political imperative for framing seasonal worker schemes in a particular way, some of which is about justifying the function of international organisations.

\section{Background and design}

Guest worker migration schemes were developed in post war Europe to provide a temporary and steady labour supply to reconstruct economies that were devasted by the Second World War and generally involving a south to north movement. As schemes developed, they became more organised with the elaboration of institutional arrangements in sending and receiving countries (Penninx, 2016). Penninx draws attention to the fact that destination countries defined themselves as 'non-immigration countries', stressing the temporary nature of the work contracts. Despite this, over time some workers brought their families, increasing the immigrant population in different European countries. These types of temporary guest worker schemes appear to be distinct to ded-

${ }^{2}$ Directive 2014/36/EU of the European Parliament and of the Council of 26 February 2014 on the conditions of entry and stay of third-country nationals for the purpose of employment as seasonal workers. 
icated seasonal programmes that tend to limit the time spent in the third country within a twelve month period and do not allow for family reunification (although the US Bracero Programme started as a seasonal scheme to help with the sugar beet harvest in 1942). The H2-A Temporary Agricultural Workers' Programme combines temporality with seasonality, being oriented to fill gaps in the domestic labour market. Workers may reside in the USA for a maximum period of up to three years and they sometimes work in seasonal roles. In reality a grey area exists between temporary and seasonal schemes.

A complex relationship exists between migration and employment where immigration regimes have been found to produce precarious employment and legal status (Strauss \& McGrath, 2017). Research shows that market forces wield undue influence as business interests remain central in the design of migration policy (Favell \& Hansen, 2002). Despite this complexity, policy makers face a major tension in seasonal schemes in ensuring an adequate level of rights for workers, protecting them against exploitation and upholding basic human rights while ensuring appropriate flows of immigrants. This tension was brought to the fore through the development of the EUs seasonal worker directive. As originally conceived it was largely focused on providing a labour supply for the internal market to foster economic growth (advanced largely by the European Commission) without a firm commitment to equality (the European Parliament lobbied for the rights of migrant workers' to avoid exploitation) (Fudge \& Herzfeld Olsson, 2014).

Most schemes including the Canadian Temporary Foreign Worker Program (TFWP), Australia's Seasonal Agricultural Worker's Programme and the RSE scheme in New Zealand, place specific duties with employers and workers. This includes the provision of affordable accommodation that meets minimum standards, travel to the workplace (if relevant), wages that are not less than native-born workers and in certain schemes (e.g. RSE) workers need to hold health insurance (Hennebry, 2012; Gibson \& McKenzie, 2014; Brickenstein, 2015). Schemes have been criticised on a number of grounds, including the fact that they are inherently exploitive and because there is no pathway to citizenship (Preibisch, 2011). Inadequate monitoring of the Canadian programme results in some employers acting illegally by charging recruitment and immigration fees (Preibisch \& Hennebry, 2012). For instance, rules require that while different jobs are likely to command different wages, there should be no difference in wages paid to immigrant workers compared to Canadians. However, employers have been shown to exploit their position by threatening job loss, deportation and criminalisation (through actual or imagined breaches to the terms of their work permit) (Strauss \& McGrath, 2017) and by charging recruitment, travel and immigration fees to workers, even though it is illegal (Hennebry \& Preibisch, 2012). The extent of exploitation is such that it represents a form of 'unfreedom' resulting from relationships that are institutionalised by employers and the state and manifest in workers who are very restricted in what they are able to do (Fudge \& Herzfeld Olsson, 2014; Strauss \& McGrath, 2017). This is countered with positive language used to promote migration schemes, including the claim made by those in the migration policy community of triple wins where the host society gains from flexible labour, the sending country benefits from remittances and skill transfers and migrants themselves gain from access to labour markets (Ruhs, 2002; Ramasamy, Krishnan, Bedford \& Bedford, 2008; Geiger \& Pécoud, 2014). Even so, a persuasive argument is made that in the absence of sponsored programmes, some migrants will exist irregularly and have only limited rights (Carens, 2013).

The question of whether seasonal workers seek citizenship is much less explored in the literature. Hugo argues that the best type of seasonal worker scheme, workers have no intention of moving permanently, instead 'circular migration is a preferred strategy' (2009, p.31). Seasonal workers may return year after year, depending on restrictions related to the scheme. For instance, 
in Canada, agricultural workers' stay in the TFWP is limited to eight months in any twelve-month period. Workers rely on specific sponsorship and they are tied to employers.

\section{Scope of temporary worker programmes}

The framing for a temporary worker programme is imperative as it defines who is able to participate and obviously also has implications for those who are not included. Many economies have temporary immigration schemes that are leaky in that they offer alternative routes that allow immigrants to undertake similar, if not identical roles. For instance, temporary worker programmes can provide an entry point for agricultural workers as an alternative to dedicated seasonal worker schemes. The existence of a temporary worker scheme means that agricultural workers can be employed through this or a dedicated seasonal agriculture worker program. Preibisch and Bindford (2007) show how, in Canada, this can result in employers 'country surfing' as they engage in com petition for workers. Fear due to uncertainty around jobs and tension between different national groups can result in migrants' misrecognition more widely as being unworthy workers (McAreavey, 2017a).

The Australian Seasonal Worker Scheme (SWS) which began in 2008 and became a full programme in 2012, was designed to enable Pacific Islanders to temporarily work in the horticulture sector (Curtain, Dornan, Howes \& Sherrell, 2018). Initially it had a very limited uptake of workers not even reaching the pilot cap of 2,500 up to March 2012 (despite claims of acute worker shortages) and it was generally not considered a success, with indications of a lack of historical interest or knowledge of the scheme (Ball, Beaucraft \& Lindley, 2011; Hay \& Howes, 2012; Curtain et al., 2018). This was largely due to the concessions that the Australian government gave to people on Working Holiday Maker (WHM) visas who are prepared to work in rural areas, along with the prevalence of illegal workers in the horticulture industry (Ball, 2010; Doyle \& Howes, 2015). Recent figures provide an evolving picture showing a 44\% increase growth in 2018-2019 (Lawton, 2019, July 25). Given its relative short time in existence, the extent to which it contributes to social justice remains to be seen.

\section{Recognised Seasonal Employer Scheme}

New Zealand's equivalent scheme has been cited as promoting regulated labour options and as generally upholding high standards. It is recognized as one of the more progressive seasonal worker schemes, for that reason it is further scrutinised. Advantages include the stability and security provided to employers each season through the use of an increasingly experienced RSE workforce, and the associated gains in productivity as workers shift from the learning phase in the first year, to having acquired the requisite skills to perform various tasks on the orchard or vineyard (Bedford, 2013). This overcomes a criticism levelled at contract labour of producers tending to be less able to control skills, commitment or employment conditions of workers in order to meet quality standards demanded by supermarkets (Kritzinger et al., 2004). It also demonstrates fundamental recognition of a group of workers as being worthy of doing the work.

It is notable how RSE has been framed - in a context of an export market for horticulture, New Zealand growers were incentivised; they 'wanted to remove any threat to their export trade through bad publicity by stopping the use of illegal workers and improving the working conditions of the workforce' (Curtain et al., 2018, p.472). By ensuring the development of a scheme, they also removed uncertainty of workers, creating a guaranteed supply of labour. A potential crisis was offset through reframing of the entire horticulture sector to encompass growers and workers. This effectively transformed the industry to address quality and environmental standards so that it 
included responsibility towards worker health and safety and ultimately compliance with employment law and worker rights on farms (Tipples \& Whatman, 2010). Political representation, closely related to recognition, clearly has the potential to exert strong influence. In this case workers were recognised as deserving equal treatment to native born workers, but only as a result of shifts in the political domain which reframed the scope of the sector, demonstrating the importance of framing and the inter-relationship between the different pillars of social justice.

Redistribution is embedded in New Zealand's scheme, showing how economic benefits accrue to the key stakeholders - workers and employers. Hugo (2009) made a strong case for circular migration i.e. migrants moving between two places in pursuit of seasonal work, arguing that, so long as it is well designed and governed, it brings significant benefits to the individuals concerned. Indeed, over the past decade it is one strategy used by Pacific's people to spread the risk of economic failure (Gibson \& McKenzie, 2014). The way that the scheme is framed pays attention to both employers and workers. Specifically, the lead body for regulation and administration of New Zealand's RSE programme moved from immigration to business, recognising the needs of employers. But it does not end there, as other government agencies are involved, typically in maintaining the wellbeing of workers and in ensuring compliance with the standards set out in the policy.

The New Zealand programme show how well designed schemes, that is schemes that are appropriately framed (after Fraser, 2005), can generate geopolitical capital as countries develop mutually beneficial links based on their geopolitical ties and migrants have a vested interest in investing in their country of origin (Peters, 2017). Cognisant of the need for redistribution, there has been a lot of investment in the relations between sending and receiving states in the New Zealand programme to the extent that Immigration New Zealand actively promotes the triple win that is strongly associated with seasonal worker schemes. It is estimated that more than $40 \%$ of the take home income is remitted back to the Pacific, this being used on housing and education (Unerhill-Sem \& Marsters, 2017). However, this differs across different Pacific Islander groups and between different types of individuals - older and married workers remit larger amounts of money, although there is little difference between the overall amount that is earned between different age categories. The New Zealand Ministry of Foreign Affairs and Trade funds a support programme in the regions where RSE workers are employed, covering English language skills, financial literacy, health and life skills training (Bedford, 2013). Research also describes investments by employers in the host society including support for water pumps and investment in public services buildings (Bedford, 2013; Bailey, 2014).

The RSE scheme is not without its flaws. For instance, participation is not freely available for everyone, rather it is a community decision requiring connections, financial capital and compliance with local stipulations around participation e.g. abstinence from alcohol (Bailey, 2019). This indicates that it is not fully redistributive, but is channeled towards certain individuals, that is, it is framed in such a way that some are automatically excluded. For those who participate in the scheme, they can live a very segmented life in the host society. While there have been quite a few studies examining the material benefits to employees and employers, less attention has been directed towards the impact on non-material issues and the impact on host societies. Challenges include the disruption to rural life in sending countries due to extended absences of adult men and women, differential power relations due to improved financial situations and re-integration of workers who no longer participate in the scheme (Bedford, Bedford, Wall \& Young, 2017; Bailey, 2019). Bailey (2019) describes the local support structures that help care for workers' families left behind. Meanwhile in the host society demand for community services and on other infrastructure can peak at certain times of the year. The impact on social cohesion is not fully understood. Bed- 
ford et al. (2017) claim that a full cost-benefit analysis of participation by Pacific workers in the RSE initiative has not been undertaken, perhaps raising questions about the extent to which cultural, economic and political aspects of social justice have been upheld.

\section{Seasonal work in the UK}

Mindful of the apparent 'gold standard' of the New Zealand scheme, I move on to consider seasonal labour in the UK, a country that left the European Union in early 2020. Before considering the recent pilot scheme, it is essential to review earlier seasonal labour initiatives. Between 1945 and 2013 a Seasonal Agricultural Workers Scheme (SAWS) provided an immigration route for employers in the UK to satisfy labour demands in the agricultural sector. Before the closure of the scheme in 2013, SAWS had reached a quota of 21,250; a fourfold increase from the original quota (Consterdine \& Samuk, 2018). The last version of the scheme, in place from 2008 to 2013, allowed fruit and vegetable growers to employ migrant workers from Bulgaria and Romania ${ }^{3}$ to do shortterm, low-skilled agricultural work in the UK for a maximum of six months at a time. It was, in the main, an industry-run scheme with light touch enforcement from the Home Office (Consterdine \& Samuk, 2018).

Following the vote to leave the UK in 2016, fewer workers returned to the UK than in previous years (in 2017 an average of just $29 \%$ of workers had worked a previous season compared to $41 \%$ in 2016 (Department for Environment Food and Rural Affairs/National Farmers' Union). A Seasonal Workers Pilot Scheme was introduced in 2019 and will be completed at the end of 2020. It only covers part of agriculture - horticulture, and in particular edible horticulture (includes soft fruit, mushrooms and orchard fruit) as this is where significant seasonal labour shortages are being reported. Pilot operators are third party providers, matching workers to farms, and may not source labour for themselves. It enables the recruitment of a limited number of up to 2,500 temporary migrants (from Russia, Moldova and Ukraine) for specific seasonal roles in the horticultural sector for up to six months. If applicants wish to return, they need to make a fresh application. To date little information has been available on the scheme, but the pilot seems to offer basic opportunities for a limited number of workers to undertake seasonal labour.

Unlike the SAWS scheme which was a contractual arrangement between the Home Office and SAWS operators, the Pilot will be managed by the Home Office under the terms and conditions of the migration system, i.e. the Tier 5 (Temporary Worker) Seasonal Worker category. Having been created in a political climate to control migration, it is not surprising that it over emphasises the migration regime over the rights of workers.

\section{Can seasonal worker schemes be socially just?}

The article set out to consider the above question affording an understand of social justice after Nancy Fraser and posing the following question in a context of seasonal labour: what does it take for all to participate on an equal footing in social life?

\footnotetext{
${ }^{3}$ Unlike the A8 countries that were allowed unfettered access to the UK labour market when the joined the EU in 2004, full transitional controls (7 years) were imposed by the UK government on Bulgaria and Romania following the 2007 expansion of the EU which explains why workers had to come through the SAWS scheme.
} 
Low wages and poor working conditions appear to characterize positions that are filled by migrants in the agri-food labour market today. Significantly the Spanish case outlined earlier shows how seasonal workers were incorporated into the labour market through regular and irregular means. The complexity of securing legitimate documents created opportunities for alternative routes into employment which did not always protect workers' interests.

Seasonal worker schemes, like many migration policies are about restriction and control, there is little freedom for workers. But the alternative is the absence of appropriate legal routes which opens up space for illegality and heightened precarity as increased restrictions can force migrants to find alternative channels to migrate (de Haas, 2017, March 29). In other words, badly designed migration policies can be counterproductive.

There is a general assumption that profit maximizing employers will prefer irregular and minimally regulated migrants over regulated alternatives (Castles, 2006a; Anderson \& Ruhs, 2010). This principle of 'crowding out' is rejected by Curtain et al. (2018) on the basis of its oversimplification and failure to appreciate the complex system of relationships. Instead they argue that much depends on the 'extent to which regulated employees are more valued than unregulated ones and on the costs of going with the regulated option. The trade-off employers make between these costs and benefits will vary from sector to sector and country to country' (Curtain et al., 2018, p.476). Besides, seasonal schemes remove an element of uncertainty as they supply a predictable workforce compared to irregularity which is a little more uncertain. This suggests that a well-designed seasonal worker scheme has the potential to offer workers conditions where they are treated in a socially just manner. Bedford et al. convincingly show how best practice schemes recognize the 'complex system of relationships that span individuals (workers, employers, contractors, government officials), organisations (government agencies, industry organisations, unions, insurance companies, accommodation services) and communities (families and wider social groups in the islands and in the destination countries)' (2017, p.49). Important issues cutting across these different groups include industry standards, employment relationships, pastoral care responsibilities and workforce projections.

As mentioned earlier, seasonal work is generally considered to offer a triple win. This rosy icture assumes that any scheme is delivered in an effective and efficient manner attentive to quality of employment and to the care of seasonal workers; sanctioning those in breach of relevant legislation. Where this fails to happen, seasonal worker schemes can breed bonded labour and exploitation (Consterdine \& Samuk, 2018). Schemes evidently need to be very meticulously designed, leaving little room for slippage or leakage in the system because, although rules can stipulate precise conditions for employing seasonal or temporary workers, employers have been found to act with impunity. Monitoring is therefore crucial.

Some may question if a seasonal worker scheme can ever be socially just. However, the evidence suggests that a dedicated scheme has greater potential to deliver fair and just relations for individuals. Three key issues are pivotal in dedicated schemes. Firstly the relationship between sending and receiving countries as mapped out in a Memorandum of Understanding is of utmost importance to ensure that all parties have a vested interest in ensuring the welfare of workers and a positive impact on the communities affected. Lessons from New Zealand show the importance of assigning clear responsibilities to different parties, such as who will contribute to the re-integration of workers or how those workers are selected. Both parties have a responsibility to constantly review the efficacy of the scheme and to adjust accordingly so that individuals are free to participate in schemes. In New Zealand, the selection of workers by the community gives a degree of power back to the sending country and reinforces community bonds but it also create the potential for community gatekeepers to disproportionately influence participation. 
Secondly the specific rules of the programme are important. For instance the obligation for workers to have health insurance or the way in which workers are allowed to return so that they can achieve circular migration allows workers to be clear about costs and enables opportunities for mobility. In returning over a period of years, workers can generate a steady stream of income that they can use in their home country for investing in housing, health, education, among others. Scott $(2015, p .8)$ recognises the importance of this draw of 'migrants from the economic periphery to the core' bringing with it financial remittances and two-way skills transfer. It has wider benefits including for producers who benefit from increased productivity and a stable workforce. Meanwhile the way in which workers are recruited can remove the need for recruitment agencies who do not necessarily operate with the best interests of workers in mind, often skimming an unreasonable portion of wages in exchange for their services.

Finally, the host government's development of seasonal schemes needs to ensure that actual labour shortages exist and should allow for investment in welfare and pastoral support as well as close scrutiny of the programme to ensure that its integrity is upheld. Importantly, there is a danger that seasonal worker schemes are used as a means of embedding precarious labour into wider social structures.

It is clear that tailored seasonal worker schemes have real potential to overcome some of the challenges facing the agri-food sector today, but equally they obscure deep-seated structural deficiencies of that sector and the constructed reliance on a particular type of work force. While seasonal worker schemes can create opportunities for fair employment regimes, they require real investment from government to ensure proper design, monitoring and remedial action. This is not always politically desirable or feasible. The way in which seasonal worker schemes uphold the values of recognition, redistribution and representation is less than perfect. Little is known about impact on non-tangible aspects such as community, gender and family relations. However, if the 'real' cost of food is to be recognised and wider principles of social justice upheld, then these issues need to be understood and ought to underpin seasonal worker schemes.

\section{References}

Anderson, B., \& Ruhs, M. (2010). Semi-Compliance and Illegality in Migrant Labour Markets: An Analysis of Migrants, Employers and the State in the UK. Population, Space and Place, 16(3), 195-211. https:// doi.org/10.1002/psp.588

Anderson, B. (2010). Migration, immigration controls and the fashioning of precarious workers. Work, Employment and Society, 24(2), 300-317. https://doi.org/10.1177/0950017010362141

Angus, A., Burgess, P. J., Morris, J., \& Lingard, J. (2009). Agriculture and land use: Demand for and supply of agricultural commodities, characteristics of the farming and food industries, and implications for land use in the UK. Land Use Policy, 26(1), 230-242. https://doi.org/10.1016/j.landusepol.2009.09.020

Apthorpe, R. (1997). Writing Development Policy and Policy Analysis Plain and Clear. On language, Genre and Power. In C., Shore \& S., Wright (Eds.). Anthropology of Policy. Critical Perspectives on Governance and Power (pp. 43-58). London: Routledge.

Bailey, R. (2014). Working the Vines: Ni-Vanuatu Labour, Central Otago Pinot, and Economic Development in Vanuatu. In P., Howland (Ed.). Social, Cultural and Economic Impacts of Wine in New Zealand (pp. 71-85). New York and Oxon: Routledge.

Bailey, R. (2019). New Zealand's Recognised Employer Scheme (RSE). 10-year longitudinal case study. Canberra: Australian National University, Department of Pacific Affairs.

Ball, R., Beaucraft, L., \& Lindley, J. (2011). Australia's Pacific Seasonal Worker Pilot Scheme: Managing vulnerabilities to exploitation. Trends and Issues in crime and Criminal Justice, 432, pp. 8. 
Ball, R. (2010). Australia's Pacific Seasonal Worker Pilot Scheme and its Interface with the Australian Horticultural Labour Market: is it Time for Reform? Pacific Economic Bulletin, 25(1), 114-130.

Barling, D., Lang, T., \& Caraher, M. (2002). Joined-up food policy? The trials of governance, public policy and the food system. Social Policy \& Administration, 36(6), 556-574. https://doi.org/10.1111/14679515.t01-1-00304

Bedford, C. E. (2013). Picking winners? New Zealand's Recognised Seasonal Employer (RSE) policy and its impacts on employers, Pacific workers and their island-based communities. Unpublished doctoral thesis. Adelaide: University of Adelaide. Retrieved on July 26, 2019 from https://hekyll.services. adelaide.edu.au/dspace/bitstream/2440/82552/9/01front.pdf

Bedford, R., Bedford, C., Wall, J. \& Young, M. (2017). Managed Temporary Labour Migration of Pacific Islanders to Australia and New Zealand in the Early Twenty-first Century. Australian Geographer, 48(1), 37-57. https://doi.org/10.1080/00049182.2016.1266629

Breen, F. (2016). Australian Immigration Policy in Practice: a case study of skill recognition and qualification transferability amongst Irish 457 visa holders. Australian Geographer, 47(4), 491-509. https:// doi.org/10.1080/00049182.2016.1220895

Brickenstein, C. (2015). Impact Assessment of Seasonal Labor Migration in Australia and NewZealand: A win-win Situation? Asian and Pacific Migration Journal, 24(1), 107-129. https://doi. org/10.1177/0117196814565228

Calavita, K. (2005). Immigrants at the Margins: Law, Race, and Exclusion in Southern Europe. Cambridge: Cambridge University Press.

Carens, J. (2013). The ethics of immigration. Oxford: Oxford University Press.

Carolan, M. (2011). The Real Cost of Cheap Food. London: Earthscan.

Cassidy, J. (2018, June 28). Why the United States needs more Immigrants. New Yorker. Retrieved from https://www.newyorker.com/news/our-columnists/why-the-united-states-needs-more-immigrants

Castles, S. (2006a). Back to the Future? Can Europe meet its Labour Needs through Temporary Migration? International Migration Institute, University of Oxford, Working Paper 1, pp. 40.

Castles, S. (2006b). Guestworkers in Europe: A Resurrection? International Migration Review, 40(4), 741766. https://doi.org/10.1111/j.1747-7379.2006.00042.x

Clapp, J. (2016). Food (2nd ed.). London: Polity Press.

Clapp, J., \& Fuchs, D. (2009). Corporate Power in Global Agrifood Governance. Cambridge, MA: The MIT Press.

Consterdine, E., \& Samuk, S. (2018). Temporary Migration Programmes: the Cause or Antidote of Migrant Worker Exploitation in UK Agriculture. International Migration and Integration, 19, 1005-1020. https://doi.org/10.1007/s12134-018-0577-x

Crawley, H., \& Skleparis, D. (2017). Refugees, migrants, neither, both: categorical fetishism and the politics of bounding in Europe's 'migration crisis'. Journal of Ethnic and Migration Studies, 44(1), 48-64. https://doi.org/10.1080/1369183X.2017.1348224

Curtain, R., Dornan, M., Howes, S., \& Sherrell, H. (2018). Pacific seasonal workers: Learning from the contrasting temporary migration outcomes in Australian and New Zealand horticulture. Asia Pacific Policy Studies, 5, 462-480. https://doi.org/10.1002/app5.261

de Haas, H. (2017, March 29). Myths of migration: much of what we think we know is wrong. Blogspot. Retrieved from https://heindehaas.org/heins-blog/

de Haas, H., Castles, S., \& Miller, M. J. (2019). The Age of Migration (6th ed.). London: Macmillan International.

DEFRA (2019). Results from the 2018 Seasonal Labour in Horticulture End of Year Survey for England. Department for Environment, Food and Rural Affairs. Retrieved from https://assets.publishing.service. gov.uk/government/uploads/system/uploads/attachment_data/file/820589/labour-in-horticulture-survey-2018-final-25jul19.pdf

Doyle, J., \& Howes, S. (2015) Australia's Seasonal Worker Program: Demand-side Constraints and Suggested Reforms. Discussion paper. Washington, DC: World Bank Group.

FAO (2018). The State of Food Security and Nutrition in the World 2018. Building climate resilience for food security and nutrition. FAO, IFAD, UNICEF, WFP, WHO. Rome: FAO. Retrieved from https://openknowledge.worldbank.org/handle/10986/21491 
Favell, A., \& Hansen, R. (2002). Markets against politics: Migration, EU enlargement and the idea of Europe. Journal of Ethnic and Migration Studies, 28(4), 581-601. https://doi. org/10.1080/1369183021000032218

Fraser, N. (1996). Social justice in the age of identity politics: redistribution, recognition and participation. The Tanner Lectures on Human Values, Stanford University. Retrieved from http://tannerlectures.utah.edu/_documents/a-toz/f/Fraser98.pdf

Fraser, N. (2005). Reframing Justice in a Globalizing World. New Left Review, 36, pp. 31.

Fudge, J., \& Herzfeld Olsson, P. (2014). The EU Seasonal Workers Directive: When Immigration Controls Meet Labour Rights. European Journal of Migration and Law, 16, 439-466.

Garrett, P.M. (2010). Recognizing the Limitations of the Political Theory of Recognition: Axel Honneth, Nancy Fraser and Social Work. British Journal of Social Work, 40, 1517-1533. https://doi. org/10.1093/bjsw/bcp044

Geddes, A., \& Scott, S. (2010). UK Food Businesses' Reliance on Low-Wages Migrant Labour: A Case of Choice or Constraint? In M., Ruhs \& B., Anderson (Eds.). A Need for Migrant Labour? (pp. 193-218). Oxford: Oxford University Press.

Geiger, M., \& Pécoud, A. (2014). International Organisations and the Politics of Migration. Journal of Ethnic and Migration Studies, 40(6), 865-887. https://doi.org/10.1080/1369183X.2013.855071

Gertel, J., \& Sippel, S. R. (2014). Seasonal Workers in Mediterranean Agriculture. The Social Costs of Eating Fresh. London: Routledge.

Gibson, J., \& McKenzie, D. (2014). The Development Impact of a Best Practice Seasonal Worker Policy. The Review of Economics and Statistics, 96(2), 229-243. https://doi.org/10.1162/REST_a_00383

Gilbert, E. (2014). The presence of temporary labour mobility: migrant worker programs across Australia, Canada and New Zealand. In L. F., Vosko, V., Preston \& R. Latham (Eds.). Liberating temporariness?

Migration, work and citizenship in an age of insecurity (pp. 152-174). Montreal and Kingston: McGillQueen's University Press.

Goodfellow, M. (2019). Hostile Environment: How Migrants Became Scapegoats. London: Verso Books.

Hay, D., \& Howes, S. (2012). Australia's Pacific Seasonal Worker Pilot Scheme: why has take up been so low. Development Policy Centre Discussion Paper, 17. Canberra: Crawford School of Public Policy, The Australian National University.

Hennebry, J. (2012). Permanently Temporary? Agricultural Migrant Workers and their Integration in Canada. Montréal, Quebec: Institute for Research on Public Policy. Retrieved from https://irpp.org/ research-studies/permanently-temporary/

Hennebry, J., \& Preibisch, K. (2012). A Model for Managed Migration? Re-Examining Best Practices in Canada's Seasonal Agricultural Worker Program. International Migration, 50(1), 19-40. https://doi. org/10.1111/j.1468-2435.2009.00598.x

Hinrichs, C. (2014). Transitions to sustainability: A change in thinking about food systems change? Agriculture \& Human Values, 31(1), 143-155. https://doi.org/10.1007/s10460-014-9479-5

Hoggart, K., \& Mendoza, C. (2002). African immigrant workers in Spanish agriculture. Sociologia Ruralis, 39, 538-562. https://doi.org/10.1111/1467-9523.00123

Hölscher, D. (2014). Considering Nancy Fraser's Notion of Social Justice for Social Work: Reflections on Misframing and the Lives of Refugees in South Africa. Ethics and Social Welfare, 8(1), 20-38. https:// doi.org/10.1080/17496535.2012.744845

Honneth, A. (2003). On the destructive power of the third: Gadamer and Heidegger's doctrine of intersubjectivity. Philosophy \& Social Criticism, 29(1), 5-21. https://doi.org/10.1177/0191453703029001830

Honneth, A. (2005). The Struggle for Recognition: The Moral Grammar of Social Conflicts. Cambridge: Polity Press.

Hugo, G. (2009). Best Practice in Temporary Labour Migration for Development: A Perspective From Asia and the Pacific. International Migration, 47(5), 23-74. https://doi.org/10.1111/j.14682435.2009.00576.x

IOM (2019). World Migration Report 2020. Geneva: International Organization for Migration.

Irwin, J., McAreavey, R., \& Murphy, N. (2014). The Social and Economic Mobility of Ethnic Minority Communities in Northern Ireland. York: Joseph Rowntree Foundation. 
Jentsch, B., \& Simard, M. (Eds.) (2009). International Migration and Rural Areas: Cross-National Comparative Perspectives. Surrey: Ashgate.

Joppke, C. (1998). Why liberal states accept unwanted immigration. World Politics, 50, 266-293. https:// doi.org/10.1017/S004388710000811X

Karar. A. Z., Alam, N., \& Streatfield, K. P. (2009). Epidemiological transition in rural Bangladesh, 19862006. Global Health Action, 19(2). https://doi.org/10.3402/gha.v2i0.1904

Kasimis, C., Papadopoulos, A. G., \& Pappas, C. (2010). Gaining from rural migrants: migrant employment strategies and socio-economic implications for rural labour markets. Sociologia Ruralis, 50(3), 258276. https://doi.org/10.1111/j.1467-9523.2010.00515.x

Kirwan, J., Maye, D., \& Brunori, G. (2017). Reflexive governance, incorporating ethics and changing understandings of food chain performance. Sociologia Ruralis, 57(3), 357-377. https://doi.org/10.1111/ soru.12169

Koehler, J., Laczko, F., Aghazarm, C., \& Schad, J. (2010). Migration and the Economic Crisis in the European Union: Implications for Policy. Brussels: International Organisation for Migration.

Kosten, D. (2018, June 5). Immigrants as Economic Contributors: They are the New American Workforce. National Immigration Forum. Retrieved from https://immigrationforum.org/article/immigrants-as-economic-contributors-they-are-the-new-american-workforce/

Kritzinger, A., Barrientos, S., \& Rossouw, H. (2004). Global production and flexible employment in South African horticulture: experiences of contract workers in fruit exports. Sociologia Ruralis, 44(1), $17-$ 39. https://doi.org/10.1111/j.1467-9523.2004.00259.x

Lang, T., Barling, D., \& Caraher, M. (2001). Food, social policy and the environment: Towards a new model. Social Policy \& Administration, 35(5), 538-558. https://doi.org/10.1111/1467-9515.t01-1-00252

Lawrence, G., Sippel, S. R., \& Burch, D. (2015). The financialisation of food and farming. In G. M., Robinson \& D. A., Carson (Eds.). Handbook on the Globalisation of Agriculture (309-327). Cheltenham Edward Elgar.

Lawton, H. (2019, July 25). Australia's seasonal worker program now bigger than NZ's. Australia National University Blog. Retrieved from http://asiapacific.anu.edu.au/news-events/all-stories/australias-seasonal-worker-program-now-bigger-nzs

LeBaron, G. (2014). Reconceptualizing debt bondage: debt as a class-based form of labor discipline. Critical Sociology, 40(5), 763-780. https://doi.org/10.1177/0896920513512695

Lenard, P. T., \& Straehle, C. (2012). Legislated inequality: temporary labour migration in Canada. Toronto and Montreal: McGill-Queen's University Press.

McAreavey, R. (2017a). Migrant Identities in a New Immigrant Destination: Revealing the Limitations of the 'Hard Working' Migrant Identity. Population, Space and Place, 23(6), 1-14. https://doi. org/10.1002/psp.2044

McAreavey, R. (2017b). New Immigration Destinations: Migrating to Rural and Peripheral Areas. London and New York: Routledge.

McAreavey, R., \& Argent, N. (2018). Editorial: New Immigration Destinations (NID) unravelling the challenges and opportunities for migrants and for host communities. Journal of Rural Studies, 64, 148152. https://doi.org/10.1016/j.jrurstud.2018.09.006

Mullaly, B. (2002). Challenging Oppression: A Critical Social Work Approach. Oxford and New York: Oxford University Press Oxford.

Newland, K. (2010). The Governance of International Migration: Mechanisms, Processes, and Institutions. Global Governance, 16(3), 331-343.

OECD (2014). International Migration Outlook. Paris: OECD Publishing. http://dx.doi.org/10.1787/migr_ outlook-2014-en

Papadopoulos, A. G., Fratsea, L., \& Mavrommatis, G. (2018). Governing migrant labour in an intensive agricultural area in Greece: Precarity, political mobilization and migrant agency in the fields of Manolada. Journal of Rural Studies, 64, 200-209. https://doi.org/10.1016/j.jrurstud.2018.03.013

Patel, R. (2007). Stuffed and Starved: Markets, Power and the Hidden Battle for the World's Food System. London: Portobello.

Penninx, R. (2016). Old wine in new bottles? Comparing the post-war guest worker migration and the 
post 1989 migration from CEE-countries to EU-member countries. Migration, Interconnectivity and Regional Development, University of Belgrade, Serbia.

Peters, M. E. (2017). Trading barriers: immigration and the remaking of globalization. Princeton and Oxford: Princeton University Press.

Piore, M. (1979). Birds of Passage: Migrant Labour and Industrial Societies. Cambridge: Cambridge University Press.

Porter, E., \& Russel, K. (2018, June 20). Migrants are on the Rise Around the World, and myths about them are shaping Attitudes. New York Times. Retrieved from https://www.nytimes.com/interactive/2018/06/20/business/economy/immigration-economic-impact.html

Preibisch, K. (2010). Pick-Your-Own Labor: Migrant Workers and Flexibility in Canadian Agriculture. The International Migration Review, 44(2), 404-441. https://doi.org/10.1111/j.1747-7379.2010.00811.x

Preibisch, K. (2011). Migrant Workers and Changing Work-place Regimes in Contemporary Agricultural Production in Canada. International Journal of the Sociology of Agriculture and Food, 19(1), 62-82.

Preibisch, K., \& Binford, I. (2007). Interrogating racialized global labour supply: an exploration of the ethnic replacement of foreign agricultural workers in Canada. Canadian Review of Sociology and Anthropology, 44(1), 5-36. https://doi.org/10.1111/j.1755-618X.2007.tb01146.x

Ramasamy, S., Krishnan, V., Bedford, R., \& Bedford, C. (2008). The Recognised Seasonal Employer policy: seeking the elusive triple wins for development through international migration. Pacific Economic Bulletin, 23(3), 171-186.

Richardson, J. (2018). The Changing British Policy Style: From Governance to Government? British Politics, 13, 215-233.

Rogaly, B. (2008). Intensification of workplace regimes in British horticulture: the role of migrant workers. Population, Space and Place, 14, 497-510. https://doi.org/10.1002/psp.502

Ruhs, M. (2002). Temporary foreign worker programmes: Policies, adverse consequences and the need to make them work. Perspectives on Labour Migration, 6. Geneva: International Labour Office.

Ruhs, M. (2013). The Price of Rights: Regulating International Labor Migration. Princeton and Oxford: Princeton University Press.

Rye, J. F., \& Andrzejewska, J. (2010). The structural disempowerment of Eastern European migrant farm workers in Norwegian agriculture. Journal of Rural Studies, 26(1), 41-51. https://doi.org/10.1016/j. jrurstud.2009.06.003

Scott, S. (2015). Making the case for Temporary Migrant Worker Programmes: Evidence from the UK's Rural Guestworker ('SAWS') scheme. Journal of Rural Studies, 40, 1-11. https://doi.org/10.1016/j. jrurstud.2015.05.005

Scott, S. (2017). Venues and Filters in Managed Migration Policy: The Case of the United Kingdom. International Migration Review, 51(2), 375-415.

Sharma, N. (2001). On Being not Canadian: The Social Organization of 'Migrant Workers' in Canada. Canadian Review of Sociology and Anthropology, 38(4), 415-40. https://doi.org/10.1111/j.1755618X.2001.tb00980.x

Standing, G. (2008). Economic Insecurity and Global Casualisation: Threat or Promise? Social Indicators Research, 88(1), 15-30. https://doi.org/10.1007/s11205-007-9202-7

Strauss, K., \& McGrath, S. (2017). Temporary migration, precarious employment and unfree labour relations: Exploring the 'continuum of exploitation' in Canada's Temporary Foreign Worker Program. Geoforum, 78, 199-208. https://doi.org/10.1016/j.geoforum.2016.01.008

Taylor, C. (1992). The Politics of Recognition. In A., Gutmann (Ed.). Multiculturalism: Examining the Politics of Recognition (pp. 25-73). Princeton: Princeton University Press.

Tipples, R., \& Whatman, R. (2010). Employment standards in world food production - The place of GLOBALGAP supply contracts and indirect legislation. New Zealand Journal of Employment Relations, 35(3), 40-60.

Unerhill-Sem, Y., \& Marsters, E. (2017). Labour Mobility in the Pacific: A systematic literature review of development impacts. Auckland: New Zealand Institute for Pacific Research. Retrieved from https:// cdn.auckland.ac.nz/assets/NZIPR/labour-mobility-in-the-pacific.pdf 